\title{
Analisis Gaya Kepemimpinan, Motivasi Kejra, dan Lingkungan Kerja terhadap Kinerja Organisasi (Studi Pada KPRI Sejahtera Sutojayan Blitar Jawa Timur)
}

\author{
Riris Fariz Fahruri \\ Mahasiswa Magister Manajemen Pascasarjana Universitas Islam Malang \\ Email : ririzfariz@gmail.com
}

\begin{abstract}
Abstrak
Koperasi adalah salah satu badan usaha atau organisasi yang cukup berkembang di Indonesia diatur dalam UUD 1945 pasal 33. Dalam UU No. 17 Tahun 2012 disebutkan bahwa dalam pelaksanaannya koperasi memiliki prinsipprinsip yang antara lain : keanggotaannya bersifat terbuka dan sukarela, pengelolaan yang dilaksanakan secara demokratis, pembahian SHU atau sisa hasil usaha secara adil sebanding dengan besarnya usaha masing-masing anggota, pembagian balas jasa yang terbatas terhadap modal, serta kemandirian.

Tujuan penelitian ini yaitu untuk mengetahui 1) analisis gaya kepemimpinan terhadap kinerja organisasi 2) motivasi kerja terhadap kinerja organisasi 3) lingkungan kerja terhadap kinerja organisasi 4) gaya kepemimpinan, motivasi kerja, dan lingkungan kerja terhadap kinerja organisasi.

Berdasarkan hasil penelitian dan pembahasan yang telah dilakukan maka dapat ditarik kesimpulan bahwa kondisi gaya kepemimpinan pada Koperasi Pegawai Republik Indonesia "SEJAHTERA" masuk dalam kriteria baik. Hasil analisis menunjukkan bahwa dengan adanya kesesuaian gaya kepemimpinan dengan harapan karyawan. motivasi kerja karyawan pada KPRI Sejahtera Sutojayan masuk dalam kriteria tinggi. Hasil analisis Motivasi Kerja terhadap Kinerja organisasi dapat diartikan bahwa adanya dorongan karyawan untuk pemenuhan kebutuhan Fisiologis atau kebutuhan fisik,keamanan, sosial, penghargaan dan aktualisasi diri maka dapat memaksimalkan pencapaian kinerja organisasi. Serta hasil analisis menunjukkan bahwa lingkungan kerja KPRI Sejahtera Sutojayan masuk dalam kategori baik. Kondisi lingkungan kerja yang semakin baik dalam hal ini mengenai suasana kerja, hubungan dengan rekan kerja yang semakin baik, tersedianya fasilitas kerja sesuai dengan kebutuhan, kondisi fisik lingkungan kerja dalam hal ini mengenai penerangan, sirkulasi udara dan kebisingan maka pencapaian kinerja karyawan dapat dimaksimalkan. Dan dapat diketahui bahwa kinerja organisasi KPRI Sejahtera Sutojayan masuk dalam kategori tinggi. Hasil analisis menunjukkan bahwa selama ini karyawan dapat bekerja sesuai dengan prosedur yang telah ditetapkan koperasi.
\end{abstract}

Kata Kunci: Gaya Kepemimpinan, Motivasi Kerja, Lingkungan Kerja dan Kinerja Organisasi

\footnotetext{
Abstract

Cooperative is one of the business entities or organizations that is sufficiently developed in Indonesia regulated in the 1945 Constitution article 33. In Law No. 17 of 2012 stated that in the implementation of cooperatives have principles which include: membership is open and voluntary, management is carried out democratically, discussion of SHU or the remaining business results are equitably proportional to the size of the efforts of each member, the distribution of compensation is limited towards capital, as well as independence.

The purpose of this study is to find out 1) analysis of leadership style on organizational performance 2) work motivation on organizational performance 3)
} 
work environment on organizational performance 4) leadership style, work motivation, and work environment on organizational performance.

Based on the results of research and discussion that has been carried out, it can be concluded that the condition of the leadership style in the Employee Cooperative of the Republic of Indonesia "PROSPEROUS" is included in good criteria. The analysis shows that with the suitability of the leadership style with employee expectations. The work motivation of employees at KPRI Sejahtera Sutojayan is included in the high criteria. The results of the analysis of Work Motivation on Organizational Performance can be interpreted that the existence of employee encouragement to fulfill physiological needs or physical, security, social, appreciation and self-actualization needs can maximize the achievement of organizational performance. And the results of the analysis show that the work environment of KPRI Sejahtera Sutojayan is included in the good category. The condition of the working environment is getting better in this case regarding the working atmosphere, relations with colleagues are getting better, the availability of work facilities in accordance with needs, the physical condition of the work environment in this case regarding lighting, air circulation and noise, the achievement of employee performance can be maximized. And it can be seen that the performance of the KPRI Sejahtera Sutojayan organization is included in the high category. The analysis shows that all this time employees can work in accordance with procedures established by the cooperative.

Keywords: Leadership Style, Work Motivation, Work Environment and Organizational Performance

\section{PENDAHULUAN}

Organisasi atau perusahaan merupakan wadah atau tempat sekumpulan orang-orang untuk melaksanakan pekerjaan dalam rangka mencapai satu tujuan organisasi yang harus mengikuti perkembangan, dimana agar dapat meningkatkan dan mengembangkan daya saing serta produktivitas yang efektif dan efisien. Setiap organisasi pasti memiliki sebuah tujuan yang ingin dicapai dengan maksimal, untuk mengupayakan hal tersebut salah satunya yaitu dengan pengelolaan sumber daya manusia (SDM) secara efektif yang merupakan suatu aspek terpenting dari seluruh sumber daya lain yang tersedia dalam organisasi.

Koperasi di Indonesia melewati proses yang panjang hingga muncul sosok seperti Mohammad Hatta yang menjadi ikon Bapak Koperasi Indonesia. Bung Hatta diangkat sebagai Bapak Koperasi Indonesia saat Kongres Koperasi Indonesia di Bandung, Jawa Barat pada tanggal 17 Juli 1953. Sedangkan pengertian koperasi menurut Bung Hatta, Koperasi adalah usaha bersama untuk memperbaiki nasib penghidupan ekonomi berdasarkan tolong-menolong. Semangat tolong menolong tersebut didorong oleh keinginan memberi jasa kepada kawan berdasarkan "seorang buat semua dan semua buat seorang".

Koperasi Pegawai Republik Indonesia (KPRI), koperasi ini beranggotakan para pegawai negeri. Sebelum KPRI, koperasi ini bernama Koperasi Pegawai Negeri (KPN). KPRI bertujuan meningkatkan kesejateraan para pegawai negeri (anggota). KPRI dapat didirikan di lingkup departemen atau instansi. Koperasi Pegawai Republik Indonesia merupakan wadah perjuangan ekonomi rakyat bertujuan untuk meningkatkan kesejahteraan anggota perorangan beserta keluarga, pada 
khususnya dan masyarakatnya pada umumnya, dengan organisasi yang disusun secara bertingkat, mulai dari koperasi primer sampai induk dan merupakan satu dan kesatuan organisasi dan kekuatan ekonomi yang tidak dapat dipisahkan dengan yang lainnya.

KPRI Sejahtera Sutojayan, adalah Koperasi Pegawai Republik Indonesia, yang terletak di jalan muria, kelurahan kalipang kecamatan sutojayan kabupaten blitar, merupakan organisasi ekonomi yang berdiri berazaskan kekeluargaan dan gotong royong dengan tujuan memajukan kesejahteraan anggota khususnya dan masyarakat pada umumnya, serta ikut membangun tatanan perekonomian nasional dalam rangka mewujudkan masyarakat yang maju, adil dan makmur berdasarkan Undang-undang Dasar 1945. KPRI Sejahtera Sutojayan merupakan gerakan ekonomi rakyat maupun badan usaha yang berperan serta untuk mewujudkan masyarakat yang maju, adil, dan makmur, melandaskan pancasila dan undang-undang. Serta membangun diri agar menjadi kuat, mandiri berdasarkan prinsip koperasi sehingga mampu berperan menjadi soko guru perekonomian nasional.

\section{KAJIAN TEORI \\ Gaya Kepemimpinan}

Kepemimpinan merupakan salah satu unsur penting dalam manajemen, kepemimpinan dibutuhkan manusia karena adanya keterbatasan-keterbatasan tertentu pada diri manusia. Oleh sebab itu timbul kebutuhan untuk memimpin dan dipimpin. Menurut Hasibuan (2001:13) "kepemimpinan adalah gaya seorang pemimpin mempengaruhi bawahannya agar mau bekerja sama dengan bekerja efektif sesuai perintahnya". Arifin dkk (2003:128) "kepemimpinan adalah sikap dan prilaku untuk mempengaruhi para bawahan agar mereka mampu bekerja sama, sehingga membentuk jalinan kerja sama yang harmonis dengan pertimbangan aspek efesiensi dan efektifitas untuk mencapai angka produktivitas kerja sesuai dengan yang telah ditetapkan". Dari beberapa teori diatas disimpulkan bahwa kepemimpinan adalah suatu usaha untuk mempengaruhi bawahan supaya terjadi suatu kerja sama yang baik dan harmonis antara atasan dan bawahan dengan mempertimbangkan aspek efesien dan efektivitas yang telah ditetapkan. Kepemimpinan sangat menentukan dalam mencapai sasaran yang telah ditetapkan. Oleh karena itu pemimpin harus mampu mempengaruhi dan mengarahkan bawahannya. Prilaku bawahan pasti berbeda-beda oleh sebab itu pememimpin harus mengerti bagaimana cara memimpin bawahannya dengan baik, pemimpin harus memahami bagaimana cara memimpin yang cocok pada tiap-tiap individu tersebut.

\section{Motivasi Kerja}

Motivasi merupakan hal yang harus diperhatikan dalam manajemen karena motivasi dapat dijadikan alat untuk meningkatkan produktivitas kerja karyawan dan mengurangi timbulnya stress kerja pada karyawan. Disaat kinerja karyawan menurun karena berbagai sebab maka motivasilah yang dapat menjadi salah satu jalan untuk meningkatkan kembali semangat dan 
antusias untuk mencapai hasil yang maksimal. Motivasi berasal dari kata latin movere yang berarti dorongan atau menggerakkan. Menurut Robbins (2015:127) motivasi merupakan proses yang menjelaskan mengenai kekuatan arah dan ketekunan seseorang dalam upaya untuk mencapai tujuan.

Pengertian lainnya tentang motivasi dikemukakan Hasibuan (2013:143) yang menyatakan bahwa motivasi adalah pemberian daya penggerak yang menciptakan kegairahan kerja seseorang agar mereka mau bekerja sama,bekerja efektif dan terintegrasi dengan segala daya upayanya untuk mencapai kepuasan.

Menurut Moorhead dan Griffin (2013:86) Motivasi adalah serangkaian kekuatan yang melibatkan orang-orang berperilaku dengan cara yang tertentu. Sedangkan menurut Susanty dan Baskoro, 2012 Motivasi merupakan hal yang penting karena motivasi dapat menjadi penyebab, penyalur, maupun pendukung dari prilaku seseorang sehingga orang tersebut berkeinginan untuk bekerja keras dan antusias untuk mencapai hasil yang optimal.

Berdasarkan beberapa pengertian motivasi diatas maka dapat disimpulkan bahwa motivasi timbul dari diri sendiri untuk mencapai suatu tujuan tertentu dan juga bisa dikarenakan oleh dorongan orang lain. Tetapi motivasi yang paling baik adalah dari diri sendiri karena dilakukan tanpa paksaan dan setiap individu memiliki motivasi yang berbeda untuk mencapai tujuan.

\section{Lingkungan Kerja}

Lingkungan kerja dalam suatu perusahaan perlu diperhatikan, hal ini disebabkan karena lingkungan kerja mempunyai pengaruh langsung terhadap para karyawan. Lingkungan kerja yang kondusif dapat meningkatkan kinerja karyawan dan sebaliknya, lingkungan kerja yang tidak memadai akan dapat menurunkan kinerja karyawan. Kondisi lingkungan kerja dikatakan baik apabila manusia dapat melaksanakan kegiatan secara optimal, sehat, aman dan nyaman. Kesesuaian lingkungan kerja dapat dilihat akibatnya dalam jangka waktu yang lama. Lingkungan kerja yang kurang baik dapat menuntut tenaga kerja dan waktu yang lebih banyak dan tidak mendukung diperolehnya rancangan sistem kerja yang efisien.

Menurut Robbins (2010) lingkungan adalah lembaga-lembaga atau kekuatan-kekuatan diluar yang berpotensi mempengaruhi kinerja organisasi, lingkungan dirumuskan menjadi dua yaitu lingkungan umum dan lingkungan khusus. Lingkungan umum adalah segala sesuatu di luar organisasi yang memilki potensi untuk mempengaruhi organisasi. Lingkungan ini berupa kondisi sosial dan teknologi. Sedangkan lingkungan khusus adalah bagian lingkungan yang secara langsung berkaitan dengan pencapaian sasaran-sasaran sebuah organisasi.

Herman Sofyandi (2008:38) mendefinisikan "Lingkungan kerja sebagai serangkaian faktor yang mempengaruhi kinerja dari fungsi-fungsi/ aktivitas-aktivitas manajemen sumber daya manusia yang terdiri dari faktorfaktor internal yang bersumber dari dalam organisasi". Danang 
Sunyoto (2012:43) mengemukakan "Lingkungan kerja adalah segala sesuatu yang ada di sekitar para pekerja dan yang dapat memengaruhi dirinya dalam menjalankan tugas-tugas yang dibebankan, misalnya kebersihan, musik, penerangan dan lainlain." Menurut Basuki dan Susilowati (2005:40) lingkungan kerja adalah segala sesuatu yang berada di lingkungan yang dapat mempengaruhi baik secara langsung maupun tidak langsung seseorang atau sekelompok orang di dalam melaksanakan aktivitasnya.

\section{METODELOGI PENELITIAN}

\section{Jenis Penelitian}

Pada penelitian ini peneliti menggunakan jenis penelitian deskriptif dengan menggunakan pendekatakan kualitatif yaitu penelitian yang menyajikan secara langsung hakekat hubungan antara peneliti dan informan agar lebih peka dan lebih bisa menyesuaikan dengan pengaruh dan pola-pola serta nilai-nilai yang dihadapi. Hal ini sesuai dengan pendapat Nawawi (2005:63) yang mengatakan bahwa "penelitian deskriptif dapat diartikan sebagai prosedur pemecahan masalah yang diselidiki dengan mengambarkan keadaan subyek/obyek penelitian pada saat sekarang berdasarkan fakta yang tampak atau seperti apa adanya".

Alasan peneliti menggunakan penelitian deskriptif karena sesuai dengan tujuan peneliti yaitu ingin menangkap fenomena untuk mendeskripsikan gaya kepemimpinan, motivasi kerja, dan lingkungan kerja dan kinerja organisasi pada seluruh jajaran KPRI Sejahtera Sutojayan. Blitar, Jawa Timur. Menurut Bogdan dan Taylor 1975 (dalam Moleong 2014:4) "penelitian kualitatif adalah prosedur penelitian yang menghasilkan data deskriptif berupa kata-kata tertulis atau lisan dari orang-orang dan perilaku yang dapat diamati". Melalui metode kualitatif, peneliti melakukan penjelajahan pada tahap awal. Selanjutnya, peneliti mulai melakukan pengumpulan data yang mendalam untuk dianalisis berdasarkan teori yang ada atau gambaran terhadap gaya kepemimpinan, motivasi kerja, dan lingkungan kerja dan kinerja organisasi pada seluruh jajaran KPRI Sejahtera Sutojayan. Blitar, Jawa Timur.

\section{Lokasi Penelitian}

Karena keterbatasan waktu, tempat serta biaya penelitian, peneliti membatasi lokasi penelitian hanya pada satu lokasi. Penelitian ini dilakukan pada karyawan serta anggota KPRI Sejahtera Sutojayan, di Jalan Muria Kelurahan Kalipang Kecamatan Sutojayan Kabupaten Blitar. Jawa timur.

\section{Waktu Penelitian}

Penelitian ini diawali dengan survei awal pada bulan Januari sampai dengan Februari 2018, untuk dapat mengetahui bagaimana gaya kepemimpinan, motivasi kerja dan lingkungan kerja terhadap kinerja organisasi KPRI Sejahtera Sutojayan. Pengumpulan data selanjutnya dilaksanakan pada bulan Mei sampai dengan Agustus 2018.

\section{Fokus Penelitian}

Fokus penelitian ini sangat penting untuk membatasi masalah yang ada agar masalah tersebut tidak meluas. Menurut Sugiyono (2009:290) 
menyatakan bahwa "fokus dalam penelitian kualitatif yaitu berdasarkan hasil studi pendahuluan, pengalaman, referensi, dan disarankan oleh pembimbing atau orang yang dipandang ahli". Moleong (2011:297) juga menjelaskan bahwa "penetapan fokus penelitian sebagai pusat dari sebuah penelitian bertujuan untuk memberikan batasan terhadap permasalahan yang akan diteliti sehingga penelitian tersebut akan terarah". Hal tersebut disebabkan oleh dua hal yaitu batas menentukan kenyataan jamak yang kemudian mempertajam fokus dan penetapan fokus dapat lebih dekat bila dihubungkan oleh interaksi antara peneliti dengan fokus.

\section{Jenis dan Sumber Data}

Jenis data yang digunakan dalam penelitian ini adalah data primer dan data sekunder. Sumber data adalah dari mana peneliti menemukan data yang diperoleh. Sumber data diperoleh dari seseorang yang berkaitan dengan pelaksanaan permasalahan yang ada dan dapat dijadikan narasumber dalam penelitian ini. Adapun jenis dan sumber data dalam penelitian ini adalah data Primer dan Data Sekunder

\section{Tehnik Pengumpulan Data}

Teknik pengumpulan data adalah cara bagaimana peneliti mendapatkan data-data penelitian. Teknik pengumpulan data dalam penelitian yaitu tehnik observasi, wwancara, dan dokumentasi

\section{HASIL ANALISIS DATA}

1. Gaya kepemimpinan yang ditetapkan pada KPRI Sejahtera Sutojayan

\begin{tabular}{|c|c|c|c|}
\hline No. & Informan & Jabatan & Tanggapan \\
\hline 1. & Bapak Poniran & Karyawan & $\begin{array}{l}\text { "Aku tidak bisa jawab mas, } \\
\text { karena itu di tingkat manajerial. Selain } \\
\text { itu kebijakan pimpinan dalam } \\
\text { menjalankan proses pengelolaan } \\
\text { karyawan telah dilakukan sesuai } \\
\text { dengan prosedur kerja sudah secara } \\
\text { terstruktur dilakukan sehingga sebagai } \\
\text { karyawan saya harus mengikuti segala } \\
\text { bentuk petunjuk untuk melaksanakan } \\
\text { kebijakan yang telah ditetapkan dari } \\
\text { atasan. Jadi ditanya mengenai } \\
\text { keadilan dalam gaya kepemimpinan ya } \\
\text { adil atau tidak adil saya harus } \\
\text { mengikuti prosedur yang telah } \\
\text { ditetapkan". (Wawancara, } 29 \text { Agustus } \\
\text { 2018/15:35) }\end{array}$ \\
\hline 2. & Ibu Sucitia Ningsih & Karyawan & $\begin{array}{l}\text { "Dalam pelaksanaan motivasi } \\
\text { kerja menurut saya sudah adil karena } \\
\text { menurut saya sesuai dengan prosedur. } \\
\text { Seperti untuk karyawan lama dilakukan } \\
\text { job opening yang dilakukan secara } \\
\text { internal, sehingga pelaksanaan } \\
\text { motivasi kerjamerata pada setiap } \\
\text { karyawan sehingga seluruh karyawan } \\
\text { memiliki kesempatan untuk memiliki }\end{array}$ \\
\hline
\end{tabular}




\begin{tabular}{|c|c|c|c|}
\hline & & & $\begin{array}{l}\text { peluang untuk karier secara jelas } \\
\text { dalam bekerja di instansi". } \\
\text { (Wawancara, } 29 \text { Agustus 2018/15:58) }\end{array}$ \\
\hline 3. & $\begin{array}{ll}\text { Ibu Diana } & \text { Heni } \\
\text { Setiawati } & \end{array}$ & Karyawan & $\begin{array}{l}\text { "Kalau adil sih pasti, karena kita } \\
\text { masuk sini sudah melalui beberapa } \\
\text { proses dalam rangka untuk } \\
\text { pencapaian kinerja karyawan. Selain } \\
\text { itu selama ini pihak manjamen koperasi } \\
\text { juga secara professional dalam } \\
\text { penempatan kerja, dimana ketika saya } \\
\text { mau masuk kerja disini memang sesuai } \\
\text { dengan proses evaluasi dari atasan } \\
\text { dan hal tersebut ditunjukkan dengan } \\
\text { gaya kepemimpinan yang ditetapkan". } \\
\text { (Wawancara, } 29 \text { Agustus 2018/15:46) }\end{array}$ \\
\hline 4. & Ninuk Wahyumiarti & Karyawan & $\begin{array}{l}\text { "Kalau kepemimpinan yang } \\
\text { ditetapkan menurut saya sudah tepat. } \\
\text { Dari awal proses job opening sudah } \\
\text { dilakukan penilaian yang sesuai } \\
\text { dengan karakter dan kemampuan kita } \\
\text { sendiri. Sehingga dalam menjalani } \\
\text { rutinitas kerja kita bisa nyaman dan } \\
\text { mampu memaksimalkan kemampuan } \\
\text { yang dimiliki oleh karyawan sehingga } \\
\text { kebijakan motivasi kerjasaya rasakan } \\
\text { sudah sesuai dengan prosedur serta } \\
\text { sudah tepat". (Wawancara, } 29 \text { Agustus } \\
\text { 2018/15:58) }\end{array}$ \\
\hline 5. & Bapak Sunaryanto & Sekretaris & $\begin{array}{l}\text { "Sudah tepat menurut saya, } \\
\text { karena itu awal ya motivasi kerja jadi } \\
\text { saat interview awal sudah ditentukan } \\
\text { cocoknya di AO, SPO serta posisi yang } \\
\text { lainnya. Jadi kalo menurut saya } \\
\text { motivasi kerja memang telah sesuai } \\
\text { dengan prosedur yang telah ditetapkan } \\
\text { dan hal ini benar-benar telah saya } \\
\text { rasakan sesuai dengan ketentuan atau } \\
\text { harapan". (Wawancara, } 29 \text { Agustus } \\
2018 / 15: 46 \text { ) }\end{array}$ \\
\hline 6. & Bapak Samsudin & Bendahara & $\begin{array}{l}\text { "Ini ditingkat manajerial ya, saya } \\
\text { tidak bisa jawab, alasan saya karena } \\
\text { kalau sudah menyangkut masalah } \\
\text { manajerial maka saya harus mengikuti } \\
\text { semua petunjuk atau tugas yang ada. } \\
\text { Jadi kebijakan tersebut wajib untuk } \\
\text { dilaksananakan seluruh elemen yang } \\
\text { terdapat diinstansi, salah satunya yaitu } \\
\text { mengenai kebijakan kepemimpinan } \\
\text { yang ditetapkan oleh instansi dimana }\end{array}$ \\
\hline
\end{tabular}


Pascasarjana Universitas Islam Malang

\begin{tabular}{|c|c|c|c|}
\hline & & & $\begin{array}{lll}\text { saya bekerja". (Wawancara, } & 29 \\
\text { Agustus 2018/15:58) }\end{array}$ \\
\hline 7. & Bapak Moh. Zaini S.Pd & Pengawas & $\begin{array}{l}\text { "Sudah sesuai, mungkin ada } \\
\text { beberapa yang sedikit kekurangan } \\
\text { karyawan di posisi tertentu tapi bisa } \\
\text { diatasi dengan rangkap kerja karyawan } \\
\text { lain. Kondisi ini menunjukkan bahwa } \\
\text { menurut saya bahwa meskipun } \\
\text { mengalami kekurangan tenaga kerja } \\
\text { yang terdapat diperusahan namun } \\
\text { demikian upaya untuk memenuhi } \\
\text { tingkat kebutuhan karyawan tetap } \\
\text { terpenuhi. Selain itu menurut saya } \\
\text { adanya posisi yang belum maksimal } \\
\text { tersebut dikarenakan personel yang } \\
\text { kurang dan belum maksimalnya upaya } \\
\text { dari instansi untuk mengisi bagian- } \\
\text { bagian tersebut". (Wawancara, } 30 \\
\text { Agustus 2018/15:30) }\end{array}$ \\
\hline 8. & Bapak Ashari & Pengawas & $\begin{array}{l}\text { "Sangat penting, karena secara } \\
\text { periodik kebijakan kepemimpinan } \\
\text { berhubungan tingkat keamanan } \\
\text { dengan kemungkinan penyimpangan } \\
\text { dan pastinya penyegaran sehingga } \\
\text { kinerja karyawan bisa lebih optimal } \\
\text { dalam memenuhi target-target } \\
\text { perusahaan. Selain tu menurut saya } \\
\text { kepemimpinan memiliki arti yang cukup } \\
\text { penting bagi saya sehingga saya lebih } \\
\text { fokus dalam proses penyelesaian } \\
\text { pekerjaan". Pimpinan selalu } \\
\text { memberikan kesempatan untuk } \\
\text { menyampaikan pendapat dan gagasan } \\
\text { saya sehingga potensi yang saya miliki } \\
\text { dapat berkembang (Wawancara, } 29 \\
\text { Agustus 2018/15:35) }\end{array}$ \\
\hline
\end{tabular}

2. Bagaimanakah peran motivasi kerja karyawan pada KPRI Sejahtera Sutojayan?

\begin{tabular}{|l|l|l|l|}
\hline No. & Informan & Jabatan & Tanggapan \\
\hline 1. & Bapak Poniran & Karyawan & "Yang pasti tentu saja bisa \\
& & $\begin{array}{l}\text { mendapatkan ilmu baru, adanya } \\
\text { peningkatan salary, mendapat }\end{array}$ \\
& & $\begin{array}{l}\text { pengalaman baru dan selain itu } \\
\text { kebijakan motivasi kerjasendiri untuk } \\
\end{array}$ & $\begin{array}{l}\text { meminimalisir terjadinya } \\
\text { penyimpangan yang mungkin bisa }\end{array}$ \\
\hline
\end{tabular}


Pascasarjana Universitas Islam Malang

\begin{tabular}{|c|c|c|c|}
\hline & & & $\begin{array}{l}\text { terjadi. Motivasi kerjayang sesuai } \\
\text { dengan ketentuan secara langsung } \\
\text { akan memberikan jaminan bahwa hasil } \\
\text { kerja dapat secara maksimal diperoleh } \\
\text { dan sesuai dengan ketentuan yang } \\
\text { telah ditetapkan". (Wawancara, } 29 \\
\text { Agustus 2018/15:35) }\end{array}$ \\
\hline 2. & Ibu Sucitia Ningsih & Karyawan & $\begin{array}{l}\text { "Menurut saya motivasi sangat } \\
\text { penting, karena dengan motivasi kerja } \\
\text { tersebut kita bisa fokus dalam } \\
\text { mencapai kinerja yang baik selain itu } \\
\text { juga menunjang kami untuk karier } \\
\text { selanjutnya dan menghindari } \\
\text { kejenuhan dalam rutinitas kerja setiap } \\
\text { hari". (Wawancara, 29 Agustus } \\
2018 / 15: 58)\end{array}$ \\
\hline 3. & $\begin{array}{l}\text { lbu Diana Heni } \\
\text { Setiawati }\end{array}$ & Karyawan & $\begin{array}{l}\text { "Pertama untuk penyegaran, kedua } \\
\text { untuk pengisian formasi yang kosong. } \\
\text { Kedua hal tersebut menurut saya } \\
\text { merupakan langkah awal dari instansi } \\
\text { dalam rangka untuk memaksimalkan } \\
\text { potensi yang dimiliki oleh karyawan } \\
\text { dalam bekerja. Kondisi juga menjadi } \\
\text { tujuan utama yang akan dicapai oleh } \\
\text { instansi agar para karyawan memiliki } \\
\text { kemampuan secara maksimal untuk } \\
\text { bekerja dan memaksimalkan potensi } \\
\text { yang dimiliki dalam proses } \\
\text { penyelesaaian pekerjaan". } \\
\text { (Wawancara, } 29 \text { Agustus 2018/15:35) }\end{array}$ \\
\hline 4. & Ninuk Wahyumiarti & Karyawan & \\
\hline 5. & Bapak Sunaryanto & Sekretaris & $\begin{array}{l}\text { "Kalau menurut saya penting, } \\
\text { karena untuk bekerja kan kita } \\
\text { ditempatkan dulu baru kita jelas untuk } \\
\text { bekerja ke depan dan motivasi dalam } \\
\text { bekerja sangat penting dilakukan. } \\
\text { Motivasi kerja karyawan kalau menurut } \\
\text { saya akan mendukung proses } \\
\text { penyelesaian pekerjaan yang akan } \\
\text { saya lalukan, dimana dengan } \\
\text { ketepatan atas motivasi kerjasecara } \\
\text { langsung akan mendukung aktivitas } \\
\text { saya di perusahaan dan selanjutnya } \\
\text { akan mendukung upaya } \\
\text { memaksimalakan potensi saya di } \\
\text { koperasi". (Wawancara, } 29 \text { Agustus } \\
\text { 2018/15:46) }\end{array}$ \\
\hline 6. & Bapak Samsudin & Bendahara & $\begin{array}{c}\text { "Iya pasti menyeluruh untuk } \\
\text { semua karyawan, dimana dalam }\end{array}$ \\
\hline
\end{tabular}




\begin{tabular}{|l|l|l|l|}
\hline & & & $\begin{array}{l}\text { kebijakan motivasi kerja instansi selalu } \\
\text { melakukan hal-hal atau persiapan } \\
\text { secara matang sehingga proses yang } \\
\text { dilakukan dapat secara tepat untuk } \\
\text { menndukung aktivitas operasional } \\
\text { instansi. Selain itu menurut saya } \\
\text { pelaksanaan motivasi kerjamerupakan } \\
\text { bentuk ril yang dikakukan instansi } \\
\text { dalam rangka untuk membeirkan } \\
\text { jaminan agar karyawan selalu bersikap } \\
\text { professional dalam bekerja". } \\
\text { (Wawancara, 30 Agustus 2018/15:30) }\end{array}$ \\
\hline 7. & Bapak Moh. Zaini S.Pd & Pengawas & \\
\hline 8. & Bapak Ashari & Pengawas & \\
\hline
\end{tabular}

3. Hal - hal apa saja yang perlu dipertimbangkan untuk menciptakan suasana lingkungan kerja untuk mencapai keberhasilan organisasi pada KPRI Sejahtera Sutojayan?

\begin{tabular}{|c|c|c|c|}
\hline No. & Informan & Jabatan & Tanggapan \\
\hline 1. & Bapak Poniran & Karyawan & $\begin{array}{l}\text { "Adanya kebutuhan formasi kerja } \\
\text { yang berkaitan dengan upaya koperasi } \\
\text { menjadikan para pegawai untuk bekerja } \\
\text { sesuai dengan formasi kerja yang telah } \\
\text { ditetapkan. Selain itu adanya upaya } \\
\text { perusahaan untuk memberikan } \\
\text { dukungan terkait dengan jaminan } \\
\text { bahwa aktivitas para karyawan telah } \\
\text { sesuai dengan ketentuan yang } \\
\text { ditetapkan menjadikan kebijakan kerja } \\
\text { penting untuk dilakukan sehingga } \\
\text { tercipta kondisi lingkungan kerja yang } \\
\text { baik sesuai dengan harapan". } \\
\text { (Wawancara, } 30 \text { Agustus } 2018 / 15: 30 \text { ) }\end{array}$ \\
\hline 2. & Ibu Sucitia Ningsih & Karyawan & $\begin{array}{l}\text { "Yang saya alami pengalaman } \\
\text { kerja sangat mendukung meskipun } \\
\text { dasarnya semua kembali penilaian } \\
\text { pada tingkat manajerial SDM dan } \\
\text { rekomendasi pimpinan atau atasan. } \\
\text { Pengalaman kerja bisa memberikan } \\
\text { nilai lebih di hadapan atasan dalam } \\
\text { memberi evaluasi kinerja karyawan dan } \\
\text { bisa mempengaruhi pemberian } \\
\text { rekomendasi atasan dan hal tersebut } \\
\text { menjadikan lingkungan kerja tetap } \\
\text { baik". (Wawancara, 29 Agustus } \\
2018 / 15: 35)\end{array}$ \\
\hline 3. & $\begin{array}{l}\text { Ibu Diana Heni } \\
\text { Setiawati }\end{array}$ & Karyawan & $\begin{array}{l}\text { "Iya sangat mendukung, karena } \\
\text { dari pengalaman kerja bisa diliat kinerja }\end{array}$ \\
\hline
\end{tabular}




\begin{tabular}{|c|c|c|c|}
\hline & & & $\begin{array}{l}\text { kita seperti apa, dan hal tersebut } \\
\text { menjadi dasar dalam penetapan tugas } \\
\text { atau pekerjaan yang harus diselesiakan } \\
\text { oleh karyawan di perusahaan". } \\
\text { (Wawancara, } 29 \text { Agustus } 2018 / 15: 46 \text { ) }\end{array}$ \\
\hline 4. & Ninuk Wahyumiarti & Karyawan & $\begin{array}{l}\text { "Iya tentu sangat mendukung, } \\
\text { dengan banyaknya pengalaman } \\
\text { tentunya atasan lebih mudah } \\
\text { memberikan evaluasi kepada kami. } \\
\text { Jadi atasan juga memperhatikan } \\
\text { pengamalan kerja yang dimiliki oleh } \\
\text { karyawan sehinga mampu bekerja } \\
\text { secara maksimal setelah proses } \\
\text { promosi jabatan dilakukan sehingga } \\
\text { kondisi lingkungan kerja dapat } \\
\text { dimaksimalkan". (Wawancara, } 29 \\
\text { Agustus 2018/15:58) }\end{array}$ \\
\hline 5. & Bapak Sunaryanto & Sekretaris & \\
\hline 6. & Bapak Samsudin & Bendahara & \\
\hline 7. & $\begin{array}{l}\text { Bapak Moh. Zaini } \\
\text { S.Pd }\end{array}$ & Pengawas & $\begin{array}{l}\text { "Untuk level tertentu ada. } \\
\text { Biasanya berhubungan dengan masa } \\
\text { kerja karyawan. Seperti misalanya } \\
\text { untuk Front Liner pada usia } 25 \text { tahun } \\
\text { bisa ditarik ke Back Office atau mungkin } \\
\text { diberi rekomendasi atasan untuk } \\
\text { mengikuti job opening internal. Jadi } \\
\text { usia juga menentukan atas } \\
\text { penempatan promosi jabatan yang } \\
\text { akan dilakukan oleh instansi, kondisi } \\
\text { menjadikan lingkungan kerja yangbaik } \\
\text { di koperasi(Wawancara, 29 Agustus } \\
\text { 2018/15:35) }\end{array}$ \\
\hline 8. & Bapak Ashari & Pengawas & $\begin{array}{l}\text { "Kondisi lingkungan kerja yang } \\
\text { baik secara langsung memberikan } \\
\text { jaminan bahwa aktivitas operasional } \\
\text { yang dilakukan sesuai dengan harapan } \\
\text { karyawan dapat memaksimalkan } \\
\text { potensi yang dimiliki dalam bekerja di } \\
\text { koperasi". (Wawancara, 30 Agustus } \\
\text { 2018/15:30) }\end{array}$ \\
\hline
\end{tabular}

4. Hal-hal apa saja yang dapat mempengaruhi produktivitas kerja karyawan baik secara langsung maupun tidak langsung untuk menunjang kinerja organisasi?

\begin{tabular}{|c|c|c|c|}
\hline No. & Informan & Jabatan & Tanggapan \\
\hline 1. & Bapak Poniran & Karyawan & $\begin{array}{l}\text { "Kebijakan promosi sangat } \\
\text { diperlukan dan penting, karena sesuai } \\
\text { dengan manfaatnya tadi dengan } \\
\text { kenaikan jabatan, pengalaman baru, } \\
\text { ilmu baru, meminimalisir } \\
\text { penyimpangan sehingga karyawan } \\
\text { akan merasa nyaman dijamin jenjang } \\
\text { karier kerjanya. Selain itu promosi } \\
\text { jabatan dapat mendukung proses }\end{array}$ \\
\hline
\end{tabular}


Pascasarjana Universitas Islam Malang

\begin{tabular}{|c|c|c|c|}
\hline & & & $\begin{array}{l}\text { motivasi yang dilakukan oleh instansi } \\
\text { kepada karyawan sehingga para } \\
\text { karyawan memiliki dorongan untuk } \\
\text { bekerja dengan lebih baik di } \\
\text { perusahaan". (Wawancara, } 29 \text { Agustus } \\
2018 / 15: 35 \text { ) }\end{array}$ \\
\hline 2. & Ibu Sucitia Ningsih & Karyawan & $\begin{array}{l}\quad \text { "Secara prosedur akan } \\
\text { dilakukan rotasi kerja setiap } 2 \text { tahun } \\
\text { sekali. Tapi seringkali juga disesuaikan } \\
\text { juga dengan kondisi formasi jabatan } \\
\text { seperti kalau kita di posisi tidak } \\
\text { menentu mengalami rotasi kerja yang } \\
\text { berbeda dengan teman-teman di unit } \\
\text { kerja yang sering mengalami rotasi } \\
\text { kerja". (Wawancara, 29 Agustus } \\
2018 / 15: 58)\end{array}$ \\
\hline 3. & $\begin{array}{ll}\text { Ibu Diana } & \text { Heni } \\
\text { Setiawati } & \end{array}$ & Karyawan & $\begin{array}{l}\text { "Secara pribadi saya pernah } \\
\text { mendapatkan promosi jabatan dari } \\
\text { perusahaan, dengan mengikuti job } \\
\text { opening dan disertai rekomendasi dari } \\
\text { atasan". (Wawancara, } 29 \text { Agustus } \\
2018 / 15: 46 \text { ) }\end{array}$ \\
\hline 4. & Ninuk Wahyumiarti & Karyawan & $\begin{array}{l}\text { "Sangat baik sekali adanya } \\
\text { promosi jabatan. Kebetulan saya } \\
\text { pernah mengalami promosi jabatan. } \\
\text { Promosi jabatan selalu ada melalui job } \\
\text { opening dan dengan adanya } \\
\text { rekomendasi atasan". (Wawancara, } 29 \\
\text { Agustus 2018/15:58) }\end{array}$ \\
\hline 5. & Bapak Sunaryanto & Sekretaris & $\begin{array}{l}\text { "Idealnya sesuai dengan aturan } \\
\text { SDM karyawan untuk jangka waktu } 2 \\
\text { tahun sekali akan dirotasi. Tapi semua } \\
\text { dasarnya melihat evaluasi dari } \\
\text { manjerial SDM sendiri apakah } \\
\text { memungkinkan untuk dilakukan rotasi. } \\
\text { Hal ini dikarenakan kondisi terkini } \\
\text { formasi jabatan yang ada di } \\
\text { perusahaan." (Wawancara, } 29 \text { Agustus } \\
\text { 2018/15:35) }\end{array}$ \\
\hline 6. & Bapak Samsudin & Bendahara & $\begin{array}{l}\text { "Pernah sekali mengalami rotasi } \\
\text { kerja, tetapi untuk waktunya tidak } \\
\text { ditentukan dalam waktu tertentu. } \\
\text { Kebijakan mengenai rotasi tersebut } \\
\text { merupakan kebijakan dari SDM } \\
\text { sehingga seluruh aktivitas para } \\
\text { karyawan dapat dilaksanakan sesuai } \\
\text { dengan prosedur atau perintah kerja } \\
\text { yang telah ditetapkan sesuai dengan }\end{array}$ \\
\hline
\end{tabular}




\begin{tabular}{|l|l|l|l|}
\hline & & & $\begin{array}{l}\text { ketentuan yang tetapkan". } \\
\text { (Wawancara, 29 Agustus 2018/15:46) }\end{array}$ \\
\hline 7. & Bapak Moh. Zaini S.Pd Pengawas & $\begin{array}{l}\text { Upaya peningkatan kinerja } \\
\text { organisasi yaitu pihak manajemen } \\
\text { koperasi melakukan promosi jabatan, } \\
\text { demosi, rotasi kerja yang secara } \\
\text { keseluruhan digunakan untuk } \\
\text { memotivasi para karyawan untuk } \\
\text { bekerja secara maksimal. Kebijakan } \\
\text { mengenai motivasi kerja tersebut juga } \\
\text { menjadi upaya dari koperasi untuk } \\
\text { memaksimalkan potensi yang dimiliki } \\
\text { para karyawan sehingga mereka } \\
\text { benar-benar mampu untuk bekerja } \\
\text { sesuai dengan prosedur atau } \\
\text { ketentuan yang telah ditetapkan". } \\
\text { (Wawancara, 30 Agustus 2018/15:30) }\end{array}$ \\
\hline 8. & Bapak Ashari & Pengawas & $\begin{array}{l}\text { "Sudah dilakukan sesuai } \\
\text { kemampuan dan prestasi kerja, hal ini } \\
\text { ditunjukan dengan adanya upaya dari } \\
\text { perusahaan untuk menjadikan para } \\
\text { karyawan agar memiliki minat atau } \\
\text { keinginan yang tinggi untuk bekerja } \\
\text { dengan baik diperusahaan. Ketepatan } \\
\text { tersebut juga ditunjukkan dengan } \\
\text { adanya pencapain prestasi kerja para } \\
\text { karyawan dalam menjalanakan } \\
\text { aktivitas di koperasi". (Wawancara, 30 } \\
\text { Agustus 2018/15:30) }\end{array}$ \\
\hline
\end{tabular}

\section{PEMBAHASAN}

\section{Hasil Analisis Gaya Kepemimpinan pada Koperasi Pegawai Republik} Indonesia "SEJAHTERA"

Kondisi gaya kepemimpinan pada Koperasi Pegawai Republik Indonesia "SEJAHTERA" menurut karyawan adalah baik. Hasil analisis menunjukkan bahwa kepemimpinan dibutuhkan manusia, karena adanya suatu keterbatasan dan kelebihan-kelebihan tertentu pada manusia. Di satu pihak, manusia terbatas kemampuannya untuk memimpin, di pihak lain ada orang yang mempunyai kelebihan kemampuan untuk memimpin. Di sinilah timbulnya kebutuhan akan pemimpin dan kepemimpinan. Betapa pentingnya pemimpin dan kepemimpinan dalam suatu kelompok jika terjadi suatu konflik atau perselisihan diantara orang-orang dalam kelompok, maka orang-orang mencari cara pemecahan supaya terjamin keteraturan dan dapat ditaati bersama. Melalui kepemimpinan yang tepat maka dengan sendirinya upaya organisasi untuk meningkatkan kinerja para karyawan dapat terwujud. Kepemimpinan dapat memotivasi para karyawan untuk bekerja secara maksimal diperusahaan dan pada akhirnya meningkatkan kinerjanya. Kinerja menurut Hasibuan (2012:94), kinerja sebagai prestasi kerja yang mengungkapkan bahwa "prestasi kerja adalah suatu hasil yang 
dicapai seseorang dalam melaksanakan tugas-tugas yang telah dibebankan kepadanya, yang disandarkan atas kecakapan, pengalaman, dan kesungguhan serta waktu".

Seorang pemimpin yang ideal memiliki sejumlah karakter seperti jujur, kompeten, berpandangan maju, dan menginspirasi. Pemimpin memegang peran dalam mempengaruhi bawahan untuk mecapai tujuan organisasi, sedangkan kepemimpinan dalam sebuah orgnisasi menunjukan hubungan antara pemimpin dengan bawahan, serta bagaimana pemimpin tersebut mampu mengarahkan bawahannya. Pada dasarnya peran pemimpin dalam suatu organisasi ialah mengupayakan segala cara agar para bawahan dapat melakukan pekerjaannya sesuai dengan tanggung jawab dan wewenang sehingga mampu mencapai tujuan organisasi yang telah ditetapkan. Untuk itu organisasi memerlukan pemimpin yang mampu menjadi monitor penggerak perubahan (transformasi) organisasi dan pemimpin yang mampu menetapkan sasaran khusus, memonitor perkembangan, dan mengidentifikasi rewards yang diterima bawahannya apabila sasaran dapat tercapai (transaksional). Jadi keberhasilan organisasi dapat ditentukan oleh keberhasilan pemimpin dalam mempengaruhi bawahannya serta ditentukan oleh efektifitas kepemimpinannya.

Hasil analisis mneunjukkan bahwa seorang pemimpin mempunyai tanggung jawab untuk melaksanakan tugas serta tanggung jawab yang demikian dituntut adanya seorang pemimpin yang mengenal secara keseluruhan anggota organisasi sehingga dapat menumbuhkan kerja sama yang harmonis diantara komponen organisasi, disini peran pemimpin menjadi sangat penting dalam keberhasilan organisasi yang dipimpinnya dalam hal arahan (direktif), supportif, partisipatif dan orientasi prestasi untuk kepuasan kerja, komitmen organisasi dan kinerja bawahannya. Hasibuan (2002), menyatakan bahwa adanya hubungan kepemimpinan dengan kinerja anggota fungsi kepemimpinan yang paling penting adalah memberikan motivasi kepada bawahannya, kepemimpinan diyakini memiliki pengaruh terhadap perusahaan dalam bentuk non keuangan.

Pemimpin memotivasi pengikutnya untuk melakukan sesuatu (kinerja) diluar dugaan (beyond normal expectation) melalui transformasi pemikiran dan sikap mereka untuk mencapai kinerja diluar dugaan tersebut, pemimpin menunjukkan berbagai perilaku berikut: pengaruh idealisme, motivasi insporasional, stimulasi intelektual dan konsiderasi individual. Suatu determinasi penting dari kinerja individu adalah motivasi. Namun motivasi bukanlah satu-satunya determinan, variabel-variabel lain: seperti usaha yang diberikan, kemampuan pengalaman masa lalu juga mempengaruhi kinerja. Dengan adanya motivasi, maka terjadilah kemauan kerja dan dengan adanya kemauan untuk bekerja serta dengan adanya kerja sama., maka kinerja akan meningkat. Kinerja karyawan merupakan tolok ukur kinerja perusahaan, semakin tinggi kinerja karyawan semakin tinggi pula kinerja perusahaan.

Menurut Paul Hersey dan Blanchard Miftah Thoha, (1996) kepemimpinan didasarkan pada saling berhubungan diantaranya hal-hal berikut ini: 1) Jumlah petunjuk dan pengarahan yang diberikan oleh 
pimpinan 2) Jumlah dukungan sosio-emosional yang diberikan oleh pemimpin 3) Tingkat kesiapan atau kematangan para pengikut yang ditunjukan dalam melaksanakan tugas khusus, fungsi atau tujuan tertentu. Kepemimpinan yang diterapkan tersebut terkait secara langsung dengan upaya peningkatan kinerja.

\section{Hasil analisis Motivasi Kerja pada karyawan Koperasi Pegawai Republik Indonesia "SEJAHTERA"}

Hasil analisis menunjukkan bahwa motivasi kerja karyawan Koperasi Pegawai Republik Indonesia "SEJAHTERA" masuk dalam kategori tinggi. Usaha untuk meningkatkan kinerja karyawan, diantaranya adalah dengan memmemberikan motivasi bagi karyawannya. Pada umumnya, orang mau bekerja untuk dapat memenuhi kebutuhan dan keinginan (fisik dan mental), baik itu kebutuhan yang disadari maupun kebutuhan yang tidak disadari. Pemenuhan kebutuhan tersebut merupakan dasar dari motivasi kerja seorang karyawan. Jika dalam proses pemenuhan kebutuhan tersebut karyawan merasakan adanya peluang dalam mencapai tujuannya, maka motivasi untuk mencapainya akan makin berlipat. Saat tujuannya tercapai, yakni pemenuhan kebutuhan, seseorang karyawan akan merasakan kepuasan dari aktivitasnya untuk memenuhi kebutuhan tersebut. Masalah yang timbul adalah bahwa kebutuhan masing-masing orang berbeda satu dengan yang lain. Maka perusahaan haruslah menjadi suatu lembaga yang menyediakan kesempatan dalam pemenuhan kebutuhan bagi para pekerjanya.

Karena menurut Miftah Thoha (1990:203), bahwa motivasi, kebutuhan, atau dorongan membuat seseorang berperilaku. Penting juga bagi perusahaan untuk mengarahkan perilaku para pekerjanya agar tercapai tujuan perusahaan secara keseluruhan dan juga tujuan individu para pekerjanya. Motivasi kerja merupakan hasrat didalam seseorang yang menyebabkan orang tersebut melakukan tindakan dan tentunya hal ini akan berpengaruh terhadap kinerja seeorang. Apabila motivasi kerja seseorang bagus maka kinerja dari orang tersebut juga pasti akan bagus begitu juga sebaliknya. Dari hasil analisis menunjukkan bahwa terdapat hubungan antara motivasi dan kinerja karyawan, dimana menurut Robbins (2006:238) bahwa seorang karyawan akan bersedia melakukan upaya yang lebih besar apabila diyakininya bahwa upaya itu akan berakibat pada penilaian kinerja yang baik, dan bahwa penilaian kinerja yang baik akan berakibat pada kenaikan gaji serta promosi, dan kesemuanya itu memungkinkan yang bersangkutan untuk mencapai tujuan pribadinya. Artinya anggota yang mempunyai motivasi yang tinggi maka cenderung memiliki kinerja yang tinggi, dan sebaliknya mereka yang kinerjanya rendah dimungkinkan karena motivasinya rendah.

\section{Hasil analisis Lingkungan Kerja pada karyawan Koperasi Pegawai Republik Indonesia "SEJAHTERA"}

Hasil analisis menunjukkan bahwa lingkungan kerja yang baik diciptakan oleh perusahaan, akan sangat bermanfaat bagi kelangsungan hidup dari perusahaan karena tidak jarang terjadi suatu perusahaan 
mengalami kerugian karena adanya lingkungan kerja yang tidak kondisif. Kondisi lingkungan kerja yang kondusif yang diciptakan oleh karyawan dan perusahaan tersebut dalam menjalankan roda organisasinya, akan menimbulkan kepuasan kerja yang tinggi karena adanya lingkungan kerja yang baik dan menyenangkan sehingga upaya peningkatan kepuasan para karyawan dalam bekerja di perusahaan dapat secara maksimal dilakukan. Lingkungan kerja yang memuaskan bagi karyawan perusahaan yang bersangkutan akan dapat meningkatkan gairah kerja di dalam perusahaan yang bersangkutan. Demikian pula sebaliknya lingkungan kerja yang tidak memuaskan akan dapat mengurangi kepuasan para karyawan dan menurunkan tingkat produktivitas kerja karyawan yang bekerja di dalam perusahaan yang bersangkutan tersebut. Hubungan antara lingkungan kerja yang baik dengan kepuasan kerja para karyawan pada suatu perusahaan tidak dapat diragukan lagi. (Ahyari, 2009:125). pengaruh hubungan yang positif yang bearti apabila variabel lingkungan kerja secara parsial naik, maka akan di ikuti oleh kenaikan kinerja karyawan . hal ini menunjukan bahwa lingkungan kerja yang baik, nyaman, dan aman dan menyenangkan akan dapat membantu karyawan dalam menyelesaikan pekerjaan masing-masing dan dapat mempengaruhi karyawan bekerja agar lebih giat dan bersemangat, sehingga di harapkan dengan adanyaa lingkungan kerja yang baik maka kinerja organisasi akan mengalami peningkatan.

\section{Hasil analisis Kinerja Organisai pada Koperasi Pegawai Republik Indonesia "SEJAHTERA"}

Berdasarkan hasil analisis yang telah dilakukan, maka dapat diketahui bahwa kinerja karyawan Koperasi Pegawai Republik Indonesia "SEJAHTERA"masuk dalam kategori tinggi.

Berdasarkan uraian di atas maka dapat dikatakan bahwa untuk mendukung prestasi akademis yang dimiliki tenaga kerja selama mengikuti pendidikan sebelumnya harus dipertimbangkan, khususnya dalam motivasi kerjatersebut untuk menyelesaikan tugas pekerjaan dan dukungan pelaksanaan diklat akan memberikan dukungan terkait dengan upaya untuk mendapatkan karyawan yang benar-benar sesuai dengan harapan. Upaya untuk mengemban wewenang dan tanggung jawab yang ditetapkan oleh perusahaan memperoleh dukungan dari pelaksanaan diklat yang dilakukan oleh perusahaan. Dalam penempatan karyawan peranan diklat yang perlu dipertimbangkan tidak terbatas pada jenjang terakhir pendidikan tetapi termasuk jenjang pendidikan yang pernah dialaminya.

Menurut Tampubolon (2007:42), perilaku dan strategi sebagai hasil kombinasi dari falsafah, keterampilan, sifat, sikap, yang sering diterapkan seorang pemimpin ketika mencoba mempengaruhi kinerja bawahanya. Mulyadi dan Rivai (2009;73), menyatakan bahwa perusahaan harus memperhatikan kondisi yang diberikan perusahaan kepada karawan akan mempengaruhi pencapaain kinerja organisasi. Timple (1992:31) dalam Mangkunegara (2009:15), menyatakan faktor-faktor kinerja terdiri dari faktor internal dan faktor eksternal.

Faktor internal (disposisional) yaitu faktor yang dihubungkan dengan 
sifat-sifat seseorang, misalnya kinerja seseorang baik disebabkan karena mempunyai kemampuan tinggi dan seorang itu tipe pekerja keras, sedangkan orang tersebut mempunyai kemampuan rendah dan orang tersebut tidak memiliki upaya-upaya untuk memperbaiki kemampuannya. Faktor eksternal yaitu faktor-faktor yang mempengaruhi kinerja seseorang yang berasal dari lingkungan, seperti perilaku, sikap, dan tindakan-tindakan rekan kerja, bawahan atau pimpinan, fasilitas kerja, dan iklim organisasi. Seseorang karyawan yang menganggap kinerjanya baik berasal dari faktorfaktor internal seperti kemampuan atau upaya, diduga individu tersebut akan mengalami lebih banyak perasaan positif tentang kinerjanya dibandingkan dengan jika menghubungkan kinerjanya yang baik dengan faktor eksternal.

\section{SIMPULAN DAN SARAN}

Berdasarkan hasil penelitian dan pembahasan yang telah dilakukan maka dapat ditarik kesimpulan sebagai berikut :

1. Hasil Analisis Gaya Kepemimpinan pada Koperasi Pegawai Republik Indonesia "SEJAHTERA"

Berdasarkan hasil analisis dapat diketahui bahwa kondisi gaya kepemimpinan pada Koperasi Pegawai Republik Indonesia "SEJAHTERA" masuk dalam kriteria baik. Hasil analisis menunjukkan bahwa dengan adanya kesesuaian gaya kepemimpinan dengan harapan karyawan.

2. Hasil analisis Motivasi Kerja pada karyawan Koperasi Pegawai Republik Indonesia "SEJAHTERA".

Hasil analisis menunjukkan bahwa motivasi kerja karyawan pada KPRI Sejahtera Sutojayan masuk dalam kriteria tinggi. Hasil analisis dapat diartikan bahwa adanya dorongan karyawan untuk pemenuhan kebutuhan Fisiologis atau kebutuhan fisik,keamanan, sosial, penghargaan dan aktualisasi diri maka dapat memaksimalkan pencapaian kinerja organisasi

3. Hasil analisis Lingkungan Kerja pada karyawan Koperasi Pegawai Republik Indonesia "SEJAHTERA".

Berdasarkan hasil analisis menunjukkan bahwa lingkungan kerja KPRI Sejahtera Sutojayan masuk dalam kategori baik. Kondisi lingkungan kerja yang semakin baik dalam hal ini mengenai suasana kerja, hubungan dengan rekan kerja yang semakin baik, tersedianya fasilitas kerja sesuai dengan kebutuhan, kondisi fisik lingkungan kerja dalam hal ini mengenai penerangan, sirkulasi udara dan kebisingan maka pencapaian kinerja karyawan dapat dimaksimalkan.

4. Hasil analisis Kinerja karyawan Koperasi Pegawai Republik Indonesia "SEJAHTERA".

Berdasarkan hasil analisis dapat diketahui bahwa kinerja organisasi KPRI Sejahtera Sutojayan masuk dalam kategori tinggi. Hasil analisis menunjukkan bahwa selama ini karyawan 
dapat bekerja sesuai dengan prosedur yang telah ditetapkan koperasi

Setelah mempelajari, menganalisis dan menyimpulkan dari hasil penelitian, maka diajukan beberapa saran yaitu sebagai berikut :

a. KPRI Sejahtera Sutojayan.

1. Diharapkan pimpinan selalu memberikan dorongan kepada pegawai sehingga pekerjaan dapat diselesaikan sesuai dengan ketentuan dan memberikan dukungan atas upaya memaksimalkan kemampuan yang dimiliki para pegawai.

2. Pimpinan harus menetapkan batas waktu dalam proses penyelesaian pekerjaan sehingga pekerjaan dapat selesai tepat pada waktunya dan sesuai dengan ketentuan yang ditetapkan instansi.

3. Pihak manajemen harus memberikan dorongan atau motivasi kepada pegawai agar menyelesaikan pekerjaan yang menjadi tanggungjawab sesuai dengan ketentuan yang ditetapkan. Bentuk dorongan tersebut yaitu dengan memberikan pemenuhan kebutuhan pegawai dalam bekerja, yaitu pemberian gaji sesuai dengan kebutuhan dan memberikan pengakuan atas pencapaian kinerja para karyawan.

4. Pihak manajemen harus memperhatikan mengenai kondisi lingkungan kerja yang terdapat di instansi yaitu dengan tetap menjaga hubungan baik dengan pegawai, memperhatikan kondisi lingkungan fisik yang terdapat di koperasi sehingga dapat mendukung aktivitas operasional koperasi.

\section{DAFTAR PUSTAKA}

Alex S. Nitisemito. 1996. Manajemen Personalia (Sumber Daya Manusia). Jakarta : Ghalia Indonesia

Amins, Ahmad. 2012. Manajemen Kinerja Pemerintah Daerah.Yogyakarta: Laksbag PRESSindo.

Arikunto, Suharsimi. 2010. Manajemen Penelitian. Jakarta: Rineka Cipta.

Azwar, S. 2007. Reliabilitas dan Validitas. Yogyakarta: Pustaka Pelajar.

Mangkunegara, A.A. Anwar Prabu. 2007. Manajemen Sumber Daya Manusia Perusahaan. Bandung: Remaja Rosdakarya.

Mangkunegara. 2004. Manajemen Sumber Daya Manusia Perusahaan, Bandung : PT. Remaja Rosdakarya.

Mangkuprawira, Tb. Sjafri. 2004. Manajemen Sumber Daya Manusia Strategik. Jakarta: Ghalia Indonesia.

Mondy, R. Wayne, and Robert M. Noe. 2005. Human Resource Management. Ninth Edition. USA: Prentice Hall.

Stone, RaymondJ.(2005). Human Resources Management; .Fifth Edition. Australia, Willey.

Sudarmanto. 2009. Kinerja dan Pengembangan Kompetensi SDM: Teori Dimensi Pengukuran, dan Implementasi dalam Organisasi. Yogyakarta: Pustaka Pelajar

Sugiyono. 2013. Metode Penelitian Kuantitatif, Kualitatif, Dan R\&D. Bandung: Alfabeta. 
Sugiyono. 2014. Metode Penelitian Administrasi dilengkapi metode R\&S. Bandung: Alfabeta.

Sukandarrumidi. 2012. Metodologi Penelitian. Yogyakarta: Gajah Mada University Press.

Suwatno. 2013. Manajemen SDM dalam Organisasi Publik dan Bisnis. Bandung: Alfabeta.

The Liang Gie. 1981. Efisiensi Kerja Bagi PembangunanNegara Cetakan keempat. Yogyakarta: Gajah Mada University Press.

Thoha, Miftah. 2003. Kepemimpinan dalam Manajemen : suatu pendekatan perilaku. Jakarta : Raja Grafindo Persada.

Umar, Husein. 2005. Evaluasi Kinerja Perusahaan: Teknik Evaluasi Bisnis dan Kerja Perusahaan Secara Komprehensif, Kuantitatif, dan Modern. Jakarta: Pustaka Utama.

Wahyudi, Bambang. Sumber Daya Manusia. Bandung : Sulita.

Wilson, Bangun. 2012. Manajemen Sumber Daya Manusia. Bandung : Erlangga 